
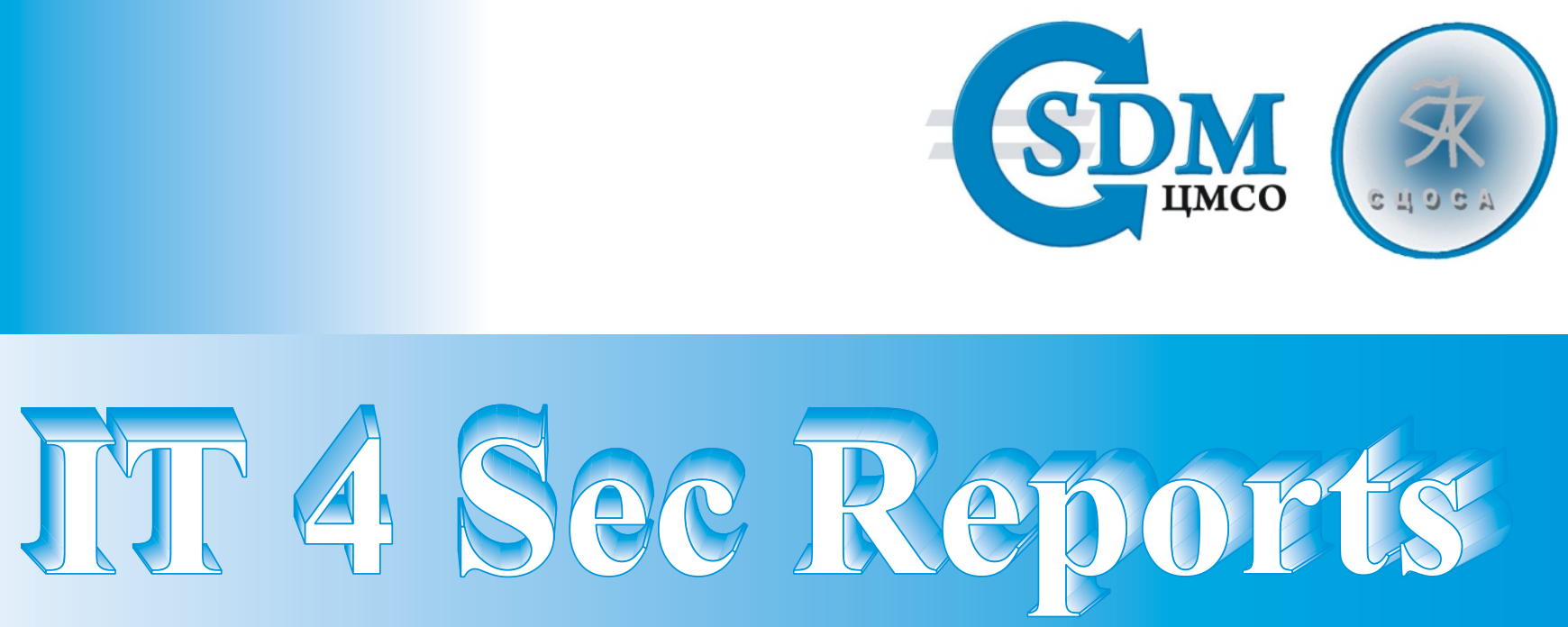

\title{
Countering Corruption in the Defence Sector: Main Risks and Challenges
}

\author{
Todor Tagarev
}

Противодействие на корупцията в отбранителния сектор: Основни рискове и предизвикателства 


\section{IT4Sec Reports 83}

\section{Countering Corruption in the Defence Sector: Main Risks and Challenges}

\section{Todor Tagarev}

Institute of Information and Communication Technologies CSDM | Centre for Security and Defence Management WWW.IT4Sec.org 
Todor Tagarev, Countering Corruption in the Defence Sector: Main Risks and Challenges, IT4Sec Reports 83 (Sofia: Centre for Security and Defence Management, May 2011).

IT4Sec Reports 83 provides the outline of a presentation to the International Conference "Strengthening Integrity and Combating Corruption in Ukraine's Defence Sector," conducted in Kyiv, Ukraine on 16 May 2011. It starts with admitting that defence is not immune to corruption. Several factors make the defence sector even more susceptible to corruption than other sectors, which sometimes manifests in unexpected forms. Hence, the corruption challenge has to be analysed comprehensively, while integrity initiatives are focused and build on success. Transparency and accountability are the most powerful tools to enhance integrity and reduce corruption in a democratic society. Their implementation in the defence sector along with other, more problem-specific measures, has to be provided in a single good governance framework. This presentation presents examples from the experience of Bulgaria that could of use to the ongoing anti corruption endeavours of the Ukrainian defence sector.

IT4Sec Reports 83 представя основните тези на доклад пред конференция на тема "Укрепване на интегритета и противодействие на корупцията в отбранителния сектор на Украйна", проведена на 16 май 2011 г. в гр. Киев. Признава се, че отбранителният сектор не е имунизиран срещу корупцията. Няколко фрактора правят този сектор дори по-податлив на корупция, понякога проявяваща се в неочаквани форми. Към предизвикателствата на корупцията следва да се подхожда всеобхватно, но инициативите за укрепване на интегритета трябва да са фокусирани и да надграждат постигнати успехи. Прозрачността и отчетността са най-мощните инструменти за укрепване на интегритета и намаляване на корупцията в демократични общества. Прилагането им в отбраната, наред с други специфични мерки, се осъществява в рамките на концепцията за добро управление. Докладът включва примери от опита на България, които могат да се използват в текущите антикорупционни усилия в отбранителния сектор на Украйна.

Key words: Good governance, integrity, transparency, accountability, defence resource management, defence audit.

Todor Tagarev is Senior Researcher at the Institute of Information and Communication Technologies of the Bulgarian Academy of Sciences and Head of its IT for Security Department, $<$ Www.IT4Sec.org $>$ and Centre for Security and Defence Management, $<$ www.defencemanagement.org $>$, Editor-in-Chief of Information \& Security: An International Journal, <http://infosec.procon.bg > and the DCAF series in Security and Defence Management.

Original version, in English, 2011

(C) Todor Tagarev

Editors: Todor Tagarev, Velizar Shalamanov, Venelin Georgiev, Zlatogor Minchev 


\section{CONTENTS}

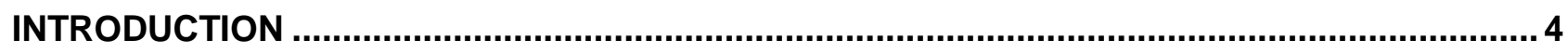

IS THERE AN “ACCEPTABLE LEVEL” OF CORRUPTION IN DEFENCE? ............................... 4

APPROACH THE ASSESSMENT OF CORRUPTION RISKS COMPREHENSIVELY;

PRIORITISE AND FOCUS ANTICORRUPTION EFFORTS

6

SHARPLY INCREASE TRANSPARENCY AND ACCOUNTABILITY;

USE AV AILABLE GOOD PRACTICE IN MEASURING RESULTS

AND PERFORMANCE

IMPLEMENT A SET OF CONSISTENT MANAGEMENT PROCESSES;

GUARANTEE PROCESS INTEGRITY 9

\section{List of Tables}

Table 1. Corruption risks in the defence sector and remedies in the experience of Bulgaria.. 7

\section{List of Figures}

Figure 1: The budget of the Bulgarian defence ministry as a percentage of the GDP, 1999-2012. 


\section{INTRODUCTION}

Corruption plagues numerous governmental and public services, and defence is not an exception. On the contrary, given the high amount of public resources dedicated to defence, the traditions of secrecy, and immature democratic control mechanisms, the sector often provides ample opportunities for corruption, particularly dire in transition towards democracy. And although in many countries the military is among the most trusted institutions, ${ }^{1}$ other studies rate it among the most corrupt of the sectors entrusted with the management of public resources. ${ }^{2}$

In this short presentation I will address four interrelated issues, namely the negative impact of corruption in the defence sector, the need to approach the problem comprehensively, the need for public transparency and accountability and, finally, the need to treat the challenges of defence resource management and corruption in a single good governance framework.

\section{IS THERE AN "ACCEPTABLE LEVEL" OF CORRUPTION IN DEFENCE?}

Reducing corruption in defence requires dedicated leadership and sustained efforts over a period of time. No one resists initiatives to reduce corruption openly, but bureaucracies often find ways to stall such efforts. Often, in private, one can hear statements on corruption being "the oil necessary to lubricate the complex defence machinery."

However-and being in Kyiv, l'll use a concept from the field of cybernetics-allowing corrupt behaviour in any form or under any disguise creates a process with a positive feedback that easily gets out of control. It strengthens behavioural patterns and impacts the morale of the defence organisation. Defence personnel, both uniformed and civilian, see that career 'success' comes not with professional merit and achievement, but in other ways. And such attitudes can be detrimental to the development and the prestige of the defence organisation. ${ }^{3}$

An example from the experience of Bulgaria is telling in that respect. For years, there have been suspicions and media hints of large scale corruption in the Bulgarian defence ministry and armed forces but only a few cases of petty corruption have been officially acknowledged. Only after the change in government in 2009, the Ministry of Defence and the law enforcement agencies started to investigate the activities of the top leadership in defence. Dozens of instances of

1 In many countries, the defence organization is perceived as less corrupt than political parties, legislatures, business enterprises, and the media; See Mark Pyman, Dominic Scott, Alan Waldron, and Inese Voika, "Building Integrity and Reducing Corruption Risk in Defense Establishments," Connections: The Quarterly Journal 7:2 (Summer 2008): 21-44.

2 A 2008 Study of Transparency International "Bribe Payers Index 2008 Table" rates defence as \# 3 among the most corrupt sectors. In the latest available study, defence fell to thirteenth on the list of industrial sectors where bribes to public officials are expected to be paid, and to eighth on the "State Capture" list.

3 For details on sources and the negative impact of corruption in the defence sector see Chapter 1 in Todor Tagarev, ed., Building Integrity and Reducing Corruption in Defence: A Compendium of Best Practices (Geneva: DCAF, 2010), <www.dcaf.ch/Publications/Publication-Detail?Ing=en\&id=113983>. 
corruption emerged and by December 2009 Bulgarian prosecutors had charged a former defence minister with abuse of power in three cases, with a fourth accusation for attempting to bribe an investigator following soon afterwards.

The official report for the first 100 days of the new government acknowledged that the defence ministry and the armed forces are at the edge of a moral crisis and stated that "main attributes of the people in defence such as duty, honour, integrity, confidence, and self-esteem were provoked by bad governance and corruption."

While important for tiding up the defence establishment from practices of mismanagement, waste and corruption, the disclosure of the scale and methods of corruption in defence increased the resentment among the people. The public trust in the defence institution further eroded. One of the consequences was the severe cut in the defence budget, never witnessed before in the history of the country (see the figure below). It is important to note that the economic crisis alone does not explain the abrupt reduction by 40 percent in one year while, given the "morale collapse" of the defence institution, no defence expert, think tank or media challenged this ruthless downsizing of the defence budget.

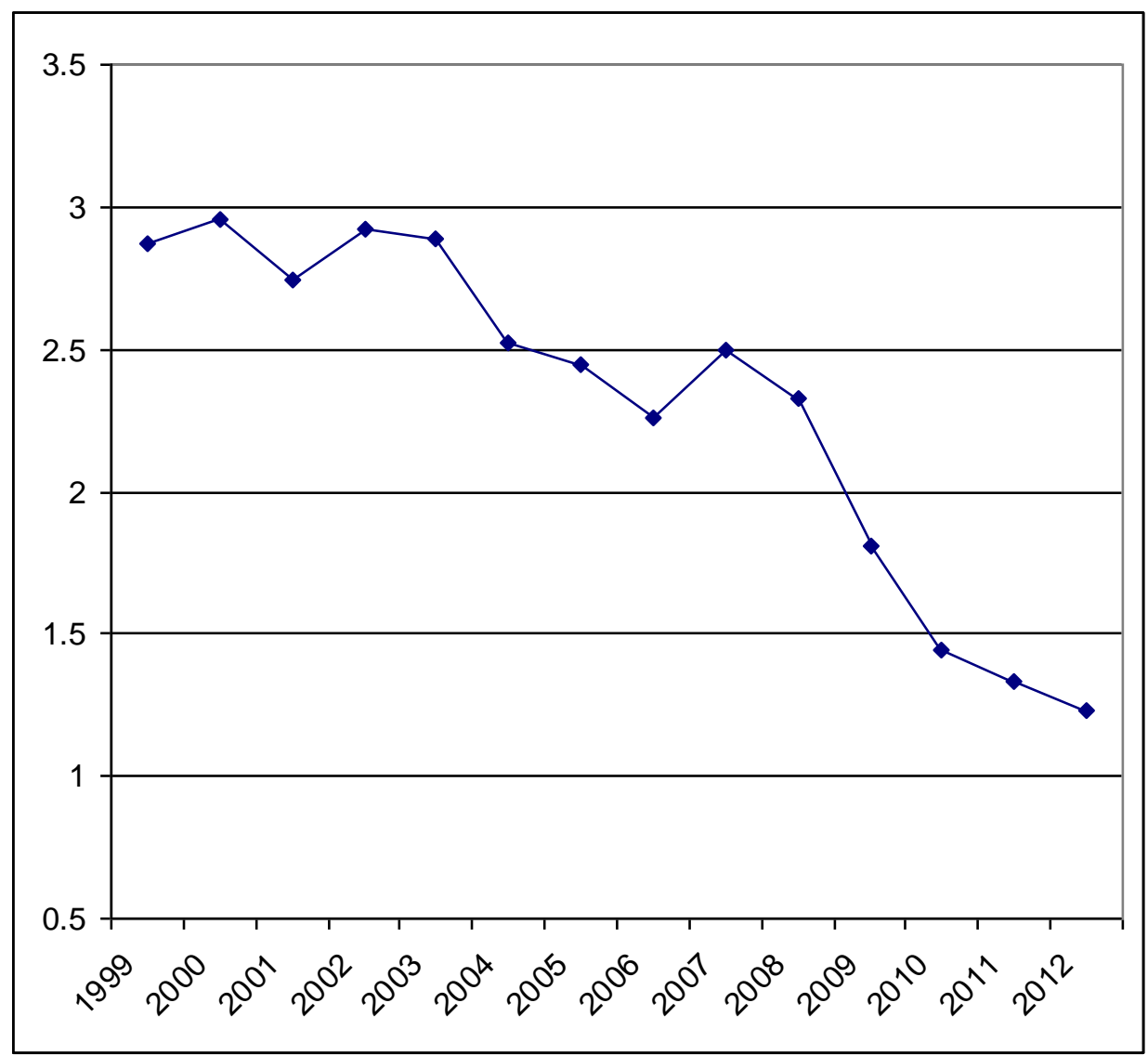

Figure 1: The budget of the Bulgarian defence ministry as a percentage of the GDP, 1999-2012.

On the other hand, this severe cut jeopardised the sustainment of the armed forces and the development of requisite capabilities, thus turning systemic corruption into a threat to national security and the international stance of the country as a reliable ally. 


\section{APPROACH THE ASSESSMENT OF CORRUPTION RISKS COMPREHENSIVELY; PRIORITISE AND FOCUS ANTICORRUPTION EFFORTS}

Western partners, willing to assist new democracies in countering corruption, may not always understand fully local problems. Their focus is often on defence procurement - an area that usually involves significant discretionary power. However, in defence establishments in the Eastern part of Europe, there are other areas that may be just as much, or even more lucrative than defence procurement.

Among the areas that are less transparent and provide opportunities for discretion without clear decision making criteria, observers often identify corruption risks in dealing with:

- excess infrastructure

- surplus weapon systems and equipment

- state- or MOD-owned defence companies

- assignment of positions in diplomatic or equivalent missions abroad

- signing up military personnel for international peace missions

- hiring defence personnel in companies contracted by the defence ministry, etc.

Therefore, when assessing corruption risks, practitioners and observers are advised to go beyond standardized assessment tools and consider resource management areas that may be particularly vulnerable to corruption in the local context.

Table 1 below presents selected experience of Bulgaria, with the corruption risk in the first column and the attempted remedy in the second.

In the example of Bulgaria, the problem of corruption in the defence sector was addressed comprehensively, in part utilising the experience of the NATO Building Integrity (BI) initiative. A comprehensive self assessment, using the standardised BI questionnaire, was reviewed by peers. ${ }^{4}$ Thus, the country identified major areas of corruption risks in the defence sector and used that understanding to adapt its anticorruption Action Plan. ${ }^{5}$

It is important to emphasise, that while Bulgaria did approach the study of corruption risks comprehensively and tried to avoid, to the extent possible, some pre-conceived notions, it did not wait for the results of comprehensive studies and the involvement of international partners. The examples in Table 1 were among early focused efforts to counter corruption that applied fairly simple but effective measures to address defence areas of high corruption risks.

4 The report itself-Bulgaria - Building Integrity Self Assessment Peer Review Report (2011)—was published on the MOD website in Bulgarian and English; For the English version see www.mod.bg/en/doc/anticorruption/20110131_Doklad_Integritet_EN.pdf.

5 For the current version of the plan, in English, see www.mod.bg/en/doc/anticorruption/20110520_ActionPlan.pdf. 
Table 1. Corruption risks in the defence sector and remedies in the experience of Bulgaria.

Transferring excess infrastructure

Transfer of surplus weapon systems
A list of all excess sites is published on the MOD website; establishment of clear rules and a transparent procedure for transfer of ownership ${ }^{6}$

All dealings with surplus weapon systems and equipment were centralised; the transparency of the procedure was significantly enhanced

Provision of housing for military personnel, particularly through barter

The policy of providing housing to the military by the MOD was clearly unaffordable and, hence, susceptible to corruption. In the limited number of cases housing was provided, the MOD exchanged lucrative land plots in big cities for apartments of often dubious value. Therefore, through recent changes in the Law on Defence and Armed Forces, the MOD abandoned that policy. ${ }^{7}$

\begin{tabular}{ll}
\hline $\begin{array}{l}\text { Appointment of personnel, } \\
\text { leaving the defence } \\
\text { establishment, by defence } \\
\text { contractors }\end{array}$ & $\begin{array}{l}\text { Recent amendments to the Law on Defence and Armed Forces } \\
\text { stipulated that a defence civilian or military officer, leaving the } \\
\text { defence establishment, is not allowed in the following three years } \\
\text { to get shares in nor work for a defence contractor, with whom } \\
\text { he/she has dealt directly or in a control/oversight capacity. }\end{array}$ \\
\hline $\begin{array}{l}\text { MOD-owned defence } \\
\text { companies, in particular their } \\
\text { procurement and } \\
\text { subcontracting practices }\end{array}$ & $\begin{array}{l}\text { In the fall of } 2010 \text { the Board of Directors of Terem SHC-state- } \\
\text { owned, MOD-managed defence holding company-mandated the } \\
\text { implementation of a corporate ethics policy in parallel with the } \\
\text { introduction of a web-based, transparent and competitive } \\
\text { subcontracting process. }\end{array}$ \\
\hline
\end{tabular}

\section{SHARPLY INCREASE TRANSPARENCY AND ACCOUNTABILITY; USE AVAILABLE GOOD PRACTICE IN MEASURING RESULTS AND PERFORMANCE}

Transparency and accountability are among the most powerful tools to counter corruption in the management of defence resources. First, that means that the defence establishment has to provide public information on the force structure, defence procurement plans, personnel policy, social policy, etc. Secondly, that requires publication not only of white papers and force development plans, but also on defence programmes, budgets, regular implementation reports, as

$6 \quad$ Lists of excess estates, updated at least bi-annually, are published on the MOD website in Bulgarian and English. For the English version see http://www.mod.bg/en/imoti.html. For other examples of good practice see Chapter 10 of Building Integrity and Reducing Corruption in Defence: A Compendium of Best Practices.

7 Law on Defence and Armed Forces of the Republic of Bulgaria, amended, State Gazette 16 (2010).

8 Law on Defence and Armed Forces, State Gazette 16 (2010), article 327a.

9 To be presented in a forthcoming book in the DCAF "Security and Defence Management" series, www.dcaf.ch. 
well as reports of independent audits. And thirdly, transparency and accountability in defence requires involvement of society, giving civil society organisations the opportunity to express their views on policy options, plans, and implementation reports.

All these may be considered textbook rules, and we know that Ukraine has achieved a lot in recent years in providing transparency and accountability at this level.

But in itself, this is only a prerequisite, i.e. not a sufficient condition, for provision of transparency and accountability. What one needs in order to reduce corruption risks is to guarantee that announced defence policies and plans are realistic, and both expectations and implementation results are measurable. This is the only way to guarantee that one limits the discretionary power of the executive in major resource decisions, and thus constrains corruption risks. When that is not the case, ample opportunities for corruption exist even when major policy decisions are made public.

For example, in 2002 the Cabinet of Ministers of Bulgaria approved a defence investment plan, known as "Plan for Modernization of the Bulgarian Armed Forces." ${ }^{10}$ The plan listed 11 'major modernization projects.' It provided a considerable level of detail, including details on the linkage with the capability development process and key capability requirements. In addition, information on the plan was distributed widely, using various venues for dissemination. ${ }^{11}$ Somewhat later, the Government approved to other lists of modernization projects of some priority, respectively with 68 and 34 procurement projects. That information was also public, with significant level of detail.

The problem was that all these procurement projects, combined, called for a level of financing exceeding at least three times the available resources. No one could predict which of these 'Government-approved' procurements would actually be realised, thus immensely increasing the discretionary power of senior defence officials, without at the same time setting adequate selection criteria and measures. Therefore, this particular case (among others) has been characterised as a 'failure' in a study of the integrity of Bulgarian defence policy. ${ }^{12}$ More recently, it came as no surprise that disclosures, coming through Wikileaks, qualified major defence procurements as related to corruption. ${ }^{13}$

In Ukraine, there is a solid tradition of involving Parliament, the President, the National Security and Defence Council and the Cabinet of Ministers in defence decision making, in addition to the decisions of the defence minister and societal involvement. The question here is whether the numerous laws, decrees, decisions and reports are coherent, set a realistic policy and provide for measuring actual results of defence activities, not just spending. A major challenge in front of the Ukrainian defence sector is to make sure that policies and results are measurable, and that 'observers,' e.g. the Audit Office, are assessing both results and performance of the defence establishment. Achieving that in a competitive setting would create major roadblocks to corruption.

10 Velizar Shalamanov, "Bulgarian Defence Reform from 1990-2008 as a Change Management Process and the Role of Integrity Building," Connections: The Quarterly Journal 8:3 (Summer 2009): 85-108.

11 See, for example, Stanimir Tchernev, "Main Challenges for the Bulgarian Armed Forces Transformation," Information \& Security: An International Journal 23:1 (2009): 18-26, $<$ http://infosec.procon.bg/v23/Tchernev.pdf>.

12 Shalamanov, "Bulgarian Defence Reform from 1990-2008 as a Change Management Process and the Role of Integrity Building," p. 92.

13 See, for example, the cables at https://www.balkanleaks.eu/wikileaks-bulgaria.html. 


\section{IMPLEMENT A SET OF CONSISTENT MANAGEMENT PROCESSES; GUARANTEE PROCESS INTEGRITY}

The final point of this short presentation is that integrity policy is neither formulated nor realised in a vacuum. Much too often, attempting to resolve problems with corruption, people with good intentions introduce stringent rules and constraints on decision making. If such attempts are not well thought out they easily stifle any initiative and may even stall the functioning of the defence administration.

Therefore, any attempts to enhance the integrity and reduce corruption in the management of defence resources have to set in a single good governance framework. Of particular importance in this respect is to provide for the integrity of a strategic management process that, even in a changing environment, preserves a clear and transparent linkage between the stages of:

- policy and long-term planning

- designing defence programmes

- budgeting, procurement, and personnel decision making

- implementation

- reporting, and

- auditing.

A recent Bulgarian experience, which may be of interest to Ukraine, is the introduction of the so called "preliminary audits," i.e. the requirement to involve auditors in the assessment of policy and procurement options prior to making the respective decisions. Thus, we hope, wasteful and corruption-prone options will be eliminated early in the process, and the country will acquire necessary defence capabilities in a more effective and efficient manner.

In conclusion, a successful integrity policy is based on the commitment of numerous players in the defence sector, not just on several anticorruption gurus. In that respect, there is rich experience in NATO, the Geneva Centre for the Democratic Control of Armed Forces and other international partners, that is available to Ukraine in its efforts to reduce corruption risks in the defence sector and increase the prestige of its military. 